\title{
A preocupação com o fazer Jornalismo a partir de sua história passada e imediata
}

Renata Costa

\section{Resumo:}

Resenha do livro História do jornalismo no Brasil

\section{Palavras Chave:}

Richard Romancini \& Claudia Lago, jornalismo, história

\section{Abstract:}

Book review História do jornalismo no Brasil

\section{Keywords:}

Richard Romancini \& Claudia Lago, journalism, history

\section{ROMANCINI, Richard e LAGO, Claudia. História do jornalismo no Brasil. Florianópolis: Insular, 2007.}

A história do jornalismo se confunde com a história do Brasil, diz qualquer livro de estudos de jornalismo. A repetição, no entanto, não torna a afirmação menos verdadeira, já que o tempo a tem comprovado como tal. Há exatos 200 anos, a família real portuguesa fugia de Napoleão e desembarcava no Rio de Janeiro trazendo no navio pessoas capacitadas e equipamentos para realizar impressões tipográficas aqui. Sempre houve tentativas - antes e depois de 1808 - para fazer circular informações pelo país, porém elas eram, na maioria das vezes, rechaçadas por Portugal, que não tinha interesse em promover a educação e o letramento na colônia. Além da questão do analfabetismo, vários outros fatores dificultavam o processo, entre eles a ausência de urbanização no país, condição quase obrigatória para o desenvolvimento da imprensa. Nesse panorama, a imprensa teimava em se desenvolver por e para poucos letrados em solo brasileiro.

Antes da chegada da família real, todo impresso deveria ser feito em Portugal e, portanto, receber o aval das autoridades do país. Com o estabelecimento da corte no Brasil, o caminho para o pedido da bênção encurtouse, mas a crítica ao reinado permanecia proibida nos folhetos que circulavam entre os brasileiros. Portanto, na "Gazeta do Rio de Janeiro», primeiro periódico rodado no país, cuja primeira edição foi lançada em 10 de setembro de 1808, o Brasil era ilusório, e questões como a independência ou a libertação dos escravos eram assuntos que passavam distantes de suas páginas.

A história da imprensa no Brasil tem sido estudada e analisada por historiadores e jornalistas. E casos como o da «Gazeta do Rio de Janeiro» facilitam as análises focadas nas relações do jornalismo com o poder. O mais famoso livro utilizado na academia e referência de leitura para alunos de jornalismo e curiosos em geral é «História da Imprensa no Brasil», de Nelson Werneck Sodré, onde o autor faz uma análise sob a perspectiva marxista das relações existentes entre o jornalismo, a imprensa e o sistema econômico.

O livro de Sodré faz uma excelente reconstituição histórica, sempre sob o ponto de vista de um historiador. Outros acadêmicos brasileiros, até mesmo jornalistas, também publicaram seus estudos nessa área com grande acuidade científica e histórica. Faltava, no entanto, que um jornalista, com linguagem jornalística clara 
e concisa, escrevesse sobre a história do jornalismo a seus pares, sem abrir mão de exaustiva pesquisa acadêmica sobre o assunto, da preocupação epistemológica e com a multicausalidade dos fatos para formar esta reconstituição histórica. Dois jornalistas se propuseram a fazer isso.

Richard Romancini e Claúdia Lago são doutores em Ciências da Comunicação pela Universidade de São Paulo, professores universitários e pesquisadores ativos em grupos reconhecidos pelo CNPq. O livro «História do Jornalismo no Brasil» supre a necessidade acadêmica de uma obra que una a história remota e recente do jornalismo, o presente e suas tendências. Deve ser, portanto, considerada indispensável pelos estudantes de jornalismo (e outros cursos de Comunicação), uma consulta ao menos aos capítulos que abrangem o período a partir da era Collor.

A utilização do termo "obra de síntese" não deve ser considerada preconceituosa e nem tampouco desmerecer o livro de Romancini e Lago. Pelo contrário, como afirma Aníbal Bragança no prefácio da primeira edição (2007: 9), os autores "devem merecer o reconhecimento de seus pares e a atenção de nossos alunos". Uma linguagem clara e acessível não anula o caráter científico da obra. As referências citadas pelos autores demonstram um levantamento exaustivo de pesquisa bibliográfica, com obras já consagradas e outras de autores mais contemporâneos que lançam olhares novos sobre a as pesquisas em jornalismo.

Além da reconstituição dos primórdios do jornalismo no país, os autores deram especial atenção à análise de notícias e fatos que marcaram a história recente ou "história imediata", como o Plano Real e o Mensalão do governo Lula, e também à análise "da dificuldade do jornalismo em consolidar-se como uma instituição fiscalizadora do Poder Executivo" (2007: 168). O episódio aponta como o jornalismo investigativo é coisa rara em um país onde a imprensa se posiciona de forma passiva aguardando fontes oficiais ou em «off», e onde os recursos que as redações destinam aos repórteres são tão ínfimos que o telefone virou a principal ferramenta de trabalho desse profissional que, na época de João do Rio, no início do século XX, era praticamente um andarilho. As questões atuais são, portanto, indubitavelmente, o ponto forte da obra e podem gerar discussões importantes no ambiente de sala de aula entre os futuros jornalistas.

Embora tenham como foco o jornalismo impresso, até pela importância e espaço que esse ocupa nas origens do que é o jornalismo no Brasil (e no mundo), os autores não deixam de citar e exemplificar o poder comunicativo nos meios eletrônicos da televisão e rádio, e mais recentemente, a presença obrigatória de todos os veículos também no mundo virtual da internet. Sendo assim, os jornalistas que viveram a passagem da máquina de escrever para o computador, o boom da internet e seus salários acima da média das redações tradicionais e a chegada da televisão a cabo no país, se sentirão testemunhas históricas das transformações dos meios de comunicação. Os estudantes de jornalismo têm a sorte de verem detalhadas e registradas essas mudanças que ouvem contar seus colegas mais velhos, e de vivenciar o nascimento dos blogs, utilizados hoje também como meio noticioso, embora o debate sobre o que é jornalismo em blog e se quem os faz é apenas e obrigatoriamente o jornalista seja uma discussão ainda em aberto.

A narrativa é permeada por apontamentos e questionamentos importantes a respeito de como as transformações, sejam elas de ordem política, econômica ou tecnológica, influenciam no mercado de trabalho para o jornalista. A evidência do crescimento dos meios de comunicação, e sua importância social central no país, faz com que Romancini e Lago levantem a preocupação indispensável de que o profissional deve ter em ser pluralista na construção da notícia, abrindo espaço para diversos pontos de vista e diferentes vozes, pois "o conjunto de preocupações das pessoas é, assim, formado cada vez mais a partir das produções simbólicas transmitidas pelos meios" (2007: 169). E é apenas desta forma que o jornalista pode cumprir seu papel social de mediador do fato/notícia e a sociedade.

Algumas discussões levantadas pelo livro, como essa, sobre o papel social do jornalista, podem até parecer um tanto óbvias para os acadêmicos, mas certamente seriam uma bênção se caíssem nas mãos dos 
profissionais que estão imersos no trabalho exaustivo das redações, especialmente naquelas de visão excessivamente mercadológica que encaram a notícia como simples "produto à venda" (MEDINA, 1988) (1).

Um povo bem informado tem poder de mudança em mãos. O acesso à informação está cada vez mais garantido, com serviços gratuitos de uso da internet. Isso não garante, no entanto, que a informação que chega à população seja de qualidade e leve em conta valores-notícia que realmente digam respeito à realidade $\mathrm{e}$ necessidade do público-leitor. Por isso, jornalistas e estudantes de jornalismo encontram no livro «História do Jornalismo no Brasil» subsídio para a análise dos rumos da imprensa no país, seu passado e presente. Que o livro desperte a preocupação epistemológica adormecida em muitos profissionais da grande imprensa.

\section{Bibliografia:}

ROMANCINI, Richard e LAGO, Claudia. História do jornalismo no Brasil. Florianópolis: Insular, 2007.

\section{Notas:}

MEDINA, Cremilda (1988). Notícia, um produto à venda - Jornalismo na sociedade urbana e industrial. São Paulo: Summus Editorial.

\section{Mini Currículo :}

Bacharel em Jornalismo pela Escola de Comunicações e Artes da Universidade de São Paulo, tem experiência profissional em reportagens e edição de textos para revistas e sites, é também mestranda em Ciências da Comunicação da mesma instituição e editora executiva da revista MATRIZes, publicação do mesmo programa de pós-graduação. 